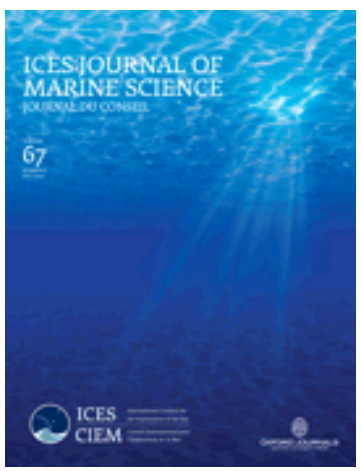

\title{
Habitat use and movement patterns of tiger sharks (Galeocerdo cuvier) in eastern Australian waters
}

\begin{tabular}{|r|l|}
\hline Journal: & ICES Journal of Marine Science \\
\hline Manuscript ID & ICESJMS-2020-407.R2 \\
\hline Danuscript Types: & Original Article \\
\hline Author: & 14 -Oct-2020 \\
\hline Complete List of Authors: & $\begin{array}{l}\text { Lipscombe, Rebecca; Southern Cross University National Marine Science } \\
\text { Centre } \\
\text { Spaet, Julia; University of Cambridge, Department of Zoology } \\
\text { Scott, Anna; Southern Cross University, National Marine Science Centre, } \\
\text { School of Environment, Science and Engineering; Southern Cross } \\
\text { University, Marine Ecology Research Centre, School of Environment, } \\
\text { Science and Engineering } \\
\text { Lam, Chi Hin; University of Massachusetts Boston, Large Pelagics } \\
\text { Research Center } \\
\text { Brand, Craig; New South Wales Department of Primary Industries, New } \\
\text { South Wales Department of Primary Industries } \\
\text { Butcher, Paul; NSW DPI, NSW Department of Primary Industries }\end{array}$ \\
\hline Keyword: & $\begin{array}{l}\text { Archival tag, Bather protection, Carcharhinid, Satellite tag, Shark } \\
\text { Management, Geolocation }\end{array}$ \\
\hline
\end{tabular}

\section{SCHOLARONE Manuscripts}


1 Habitat use and movement patterns of tiger sharks (Galeocerdo cuvier) in 2 eastern Australian waters

3

4 Rebecca S. Lipscombe ${ }^{1}$, Julia L.Y. Spaet ${ }^{2}$, Anna Scott $^{1}$, Chi Hin Lam ${ }^{3}$, Craig P. Brand ${ }^{4}$, Paul 5 A. Butcher ${ }^{1,4^{*}}$

6

$7{ }^{1}$ National Marine Science Centre, Marine Ecology Research Centre, School of Environment,

8 Science and Engineering, Southern Cross University, PO Box 4321, Coffs Harbour, NSW, 92450, Australia

$10{ }^{2}$ Evolutionary Ecology Group, Department of Zoology, University of Cambridge, Downing

11 Street, Cambridge CB2 3EJ, UK

$12{ }^{3}$ Large Pelagics Research Center, School for the Environment, University of Massachusetts 13 Boston, Gloucester, MA, United States

$14{ }^{4}$ NSW Department of Primary Industries, National Marine Science Centre, Coffs Harbour, 15 NSW 2450, Australia

$16 *$ *orresponding author: paul.butcher@dpi.nsw.gov.au +61 438650129

17

18

19

20 Keywords: Archival tag, Bather protection, Carcharhinid, Geolocation, Satellite tag, Shark 21 Management 


\section{$1 \quad$ Abstract}

2 Understanding the movement of marine predators is vital for effective conservation and

3 management. Despite being targeted by shark control programs, the tiger shark, Galeocerdo

4 cuvier, is poorly studied off eastern Australia. To investigate the horizontal movement and

5 habitat use in this region, 16 sharks (157- $384 \mathrm{~cm}$ total length) were tagged with MiniPAT

6 pop-up satellite archival tags in 2018 and 2019. Eleven of these individuals were also fitted

7 with satellite-linked radio transmitting tags. After release, most sharks moved off the

8 continental shelf and headed north, associating with seamounts as they moved toward

9 Queensland. During their time at liberty they transited through temperate, sub-tropical and

10 tropical waters and spent the majority of time in the upper $50 \mathrm{~m}$ of the water column and at

11 temperatures between $22-25^{\circ} \mathrm{C}$. Horizontal movement was focused in waters off the

12 continental shelf. Increased movement over shelf waters occurred during the austral spring

13 and summer when the East Australian Current is at its strongest and warm waters encroach

14 the continental shelf. Broad latitudinal movement along the east coast of Australia was

15 evident and highlights the connectivity between tropical and warm temperate regions. 


\section{$1 \quad$ Introduction}

2 Analysis of the spatial dynamics and patterns in shark movement has become detailed and

3 accurate, revealing complex horizontal and vertical habitat use and behavioural patterns

4 (Barnes et al., 2016; Spaet et al., 2017). While previously limited to mark-recapture studies,

5 over the last two decades, satellite and acoustic technology has increased our ability to

6 document broad-scale movement, migration, residency and philopatric behaviour (Holmes et

7 al., 2014; Werry et al., 2014). Additionally, evaluation of depth and temperature preference

8 and diving behaviour can be performed through archived data and biologging (Andrzejaczek

9 et al., 2019a) and has revealed dynamic vertical movements and plasticity of habitat use

10 (Holmes et al., 2014; Afonso and Hazin, 2015).

12 The tiger shark, Galeocerdo cuvier (Carcharhinidae), is a large predatory shark that is currently listed as 'Near Threatened' on the International Union for Conservation of Nature

14 (IUCN) Red List of threatened species (Ferreira and Simpfendorfer 2019). Galeocerdo cuvier

15 have a global distribution and utilise both nearshore and offshore habitats (Fitzpatrick et al., 16 2012; Holmes et al., 2014) in tropical and warm-temperate regions (Last et al., 2009). On the 17 east coast of Australia, G. cuvier shows a high level of interaction with commercial, 18 recreational and illegal fisheries due to its broad-scale movements (Field et al., 2009;

19 Macbeth, 2009; Butcher et al., 2015). Yet, movement along the east coast of Australia is 20 relatively undocumented, with only one previous study encompassing New South Wales 21 (NSW) and Queensland (QLD) waters (Holmes et al., 2014).

23 Interactions with fisheries are not the only management issue for G. cuvier on the east coast 24 of Australia (Butcher et al., 2015), as they are also one of the main species targeted in state shark control programs (Reid et al., 2011; Holmes et al., 2012). To minimise the threat of 
1 some shark species to water users, government shark control programs have been in place in

2 both NSW and QLD for over 50 years and use a combination of shark nets and/or baited

3 drumlines (Reid et al., 2011). Galeocerdo cuvier was among three 'target' species of shark

4 that were identified as a threat to humans, being responsible for several deaths and severe

5 injuries on the east coast of Australia (McPhee, 2014). Despite the rarity in bites, excessive

6 media attention, and increased pressure from the community and government authorities

7 (Fraser-Baxter and Medvecky, 2018), in 2015, the NSW Government implemented the

8 'Shark Management Strategy' (Simmons and Mehmet, 2018). This strategy uses a

9 multidisciplinary approach and involves the trials of alternative or new tools for bather

10 protection including SMART drumlines (Guyomard et al., 2019) and drones (Colefax et al.,

11 2019; Butcher et al., 2020).

12

13 One component of the shark management strategy in NSW is to further quantify the

14 movements and behaviour of target sharks like G. cuvier to help minimise human-shark

15 interactions. Here, we aim to characterise broad-scale movement of G. cuvier and examine

16 habitat use between coastal and pelagic environments along the east coast of Australia using

17 satellite-linked radio transmission and pop-up archival tagging technologies.

19 Materials and methods

20 Tagging

21 Targeted fishing for G. cuvier occurred between 13 February 2018 and 23 July 2019 using 22 SMART drumlines (Guyomard et al., 2019) and vertical droplines (Williams et al., 2016).

23 Sharks were caught at Lennox Head ( $\left.28^{\circ} 48^{\prime} \mathrm{S}, 153^{\circ} 36^{\prime} \mathrm{E}\right)$, Ballina (28 $\left.50^{\circ} \mathrm{S}, 153^{\circ} 33^{\prime} \mathrm{E}\right)$,

24 Evans Head $\left(29^{\circ} 06^{\prime} \mathrm{S}, 153^{\circ} 25^{\prime} \mathrm{E}\right)$ and Coffs Harbour ( $\left.30^{\circ} 17^{\prime} \mathrm{S}, 153^{\circ} 06^{\prime} \mathrm{E}\right)$, NSW, Australia.

25 SMART drumlines were baited with $0.75-1.0 \mathrm{~kg}$ sea mullet, Mugil cephalus and deployed 
$1500 \mathrm{~m}$ offshore on sandy substrate in 6-10 $\mathrm{m}$ water depth. Vessels monitoring the SMART

2 drumlines were immediately alerted of the capture via email, text message and phone call and

3 attended to the shark within $30 \mathrm{~min}$. Up to four droplines were deployed off Coffs Harbour

4 only, between $1400 \mathrm{~m}$ and $4000 \mathrm{~m}$ from shore in depths between 25-35 m over rocky reef

5 substrate. Mainlines were vertically orientated, consisting of $80 \mathrm{~m}$ of $8 \mathrm{~mm}$ diameter

6 polypropylene/polyethylene blend rope and weighted to the seabed by a $4 \mathrm{~kg}$ Danforth anchor

7 and $5 \mathrm{~m}$ of $10 \mathrm{~mm}$ galvanised chain. A large A3 polyform buoy $(43.2 \mathrm{~cm}$ diameter $\times 58.4 \mathrm{~cm}$

8 length) was attached to the top of the mainline with two smaller buoys $(27.9 \mathrm{~cm}$ diameter $\times$

$9 \quad 38.1 \mathrm{~cm}$ length) connected to the main buoy. Three gangions were attached from the top of

10 the mainline at $8 \mathrm{~m}$ intervals. Each gangion comprised of $2.8 \mathrm{~m}$ of $2 \mathrm{~mm}$ diameter stainless

11 steel wire attached to a stainless-steel clip and a 16/0 non-offset circle hook. Each hook was

12 baited with approximately $0.5 \mathrm{~kg}$ of M. cephalus or Australian salmon, Arripis trutta. All

13 sharks were kept in the water during tagging operations. Full details of the tagging procedure

14 and shark capture and handling are provided in Spaet et al. (2020a). Each shark was

15 classified as juvenile $(<259 \mathrm{~cm} \mathrm{TL})$, sub adult $(259-329 \mathrm{~cm} \mathrm{TL})$ or adult $(>330 \mathrm{~cm} \mathrm{TL})$

16 according to the life history descriptions by Werry et al. (2014) and Whitney and Crow

17 (2007).

19 Tag details and programming

\section{Archival tagging}

21 Sharks were tagged with MiniPAT pop-up satellite archival tags (PSATs), Wildlife

22 Computers (Redmond, WA, USA), to record ambient light-level, depth (accuracy $\pm 1 \%$ of

23 reading) and water temperature (accuracy $\pm 0.1{ }^{\circ} \mathrm{C}$ ). MiniPATs were pressure rated to 2000

$24 \mathrm{~m}$ and had a pre-programmed deployment of $120(\mathrm{n}=3)$ or $180 \mathrm{~d}(\mathrm{n}=13)$, after which they

25 released from the animal and commenced transmission of archived data to the ARGOS 
1 network. During deployment, tags were programmed to record and archive a time-series of

2 temperature $\left({ }^{\circ} \mathrm{C}\right)$, water depth $(\mathrm{m})$, and ambient light, with a sample interval of $5 \mathrm{~min}$ for

3 data transmission upon release. Recording of summary data occurred over $24 \mathrm{~h}$ and consisted

4 of depth-temperature profiles, light-level curves and percentage of time spent in the mixed

5 layer. If tag-defined mortality occurred, the tags inbuilt premature release device activated

6 and the tag released from the shark. Activation of this release ensued if one of the following

7 three parameters were met for four consecutive days: i) the tag was recording a constant

8 depth of $0 \mathrm{~m}$, ii) the tag was recording a constant depth $\pm 2.5 \mathrm{~m}$, or iii) the tag remained at, or

9 below $1400 \mathrm{~m}$. MiniPATs (12 cm length, volume $\left.60 \mathrm{~cm}^{3}\right)$ were tethered using a $15 \mathrm{~cm}$

10 filament of $1.3 \mathrm{~mm}$ diameter stainless steel wire covered with black heat shrink and crimped

11 at either end. Tags were secured to each shark using either a stainless-steel anchor plate

12 (Speed et al., 2013) or bolt attachment. Anchor attachment required implantation of a $5 \mathrm{~cm}$

13 titanium plate $\sim 5 \mathrm{~cm}$ into the basolateral dorsal musculature using a handheld tagging pole.

14 Tags were inserted at an angle of $45^{\circ}$ towards the shark's head, which ensured that

15 the tag assumed a trailing position on the body. Bolt attachment involved passing a

16 stainless steel bolt through the tether loop on the MiniPAT and a pre-drilled $4 \mathrm{~mm}$ hole at the

17 base of the dorsal fin in conjunction with a satellite-linked radio transmitting (SLRT; Wildlife

18 Computers 'SPOT6' tags) tag.

20 Satellite tagging

21 SPOT6 tags were used to support PSAT light-based position estimates and were positioned 22 so that the wet/dry sensor was exposed to air when the dorsal fin broke the water's surface, 23 enabling ARGOS satellites to identify the shark's location. These positions are classified on a 24 scale of decreasing accuracy using seven location classes (LC) from 3, 2, 1, 0, A, B, and Z 
1 (CLS, 2011). LC3 is the most reliable and accurate with an error of $<250 \mathrm{~m}$, LC2 has an

2 error between 250-500 m, LC1 between 500-1 $500 \mathrm{~m}$ and LC0 to LCB >1 $500 \mathrm{~m}, \mathrm{LCZ}$

3 indicates no position was recorded. SPOT6 tags (maximum battery life $280 \mathrm{~d}, 53 \mathrm{~g}$, length

$4 \quad 8.1 \mathrm{~cm}$ ) were attached to the dorsal fin using $50 \mathrm{~mm}$ stainless steel bolts.

5

6 In additon to MiniPAT and SPOT6 tags, all sharks were fitted with acoustic transmitters

7 (Supplementary Material Table S1), however, acoustic data was disregarded from the

8 analysis as only one fix existed for each shark. The study was conducted under research

9 permits from NSW DPI Scientific Research (P01/0059[A]), Marine Parks (P16/0145-1.1) and

10 Animal Care and Ethics (07/08) permits and Southern Cross University Animal Care and

11 Ethics Committee Animal Research Authority (19/036).

\section{Track reconstruction and data analysis}

14 Sharks were instrumented with satellite-linked radio transmission and pop-up satellite tags

15 that provide a myriad of positional estimates and quality. Radio fixes were all opportunistic

16 in nature, as a shark's fin needed to break the sea surface long enough to communicate with

17 an orbiting satellite. As a result, positional information was often clustered in space and time,

18 yet varied over the course of a deployment. Positioned via light-based geolocation estimation,

19 pop-up satellite archival tags offered the least accurate positions (Galuardi and Lam, 2014),

20 yet given a shark's occupancy in the epipelagic layer, good light level readings were usually

21 available throughout the deployment period. After visual inspection of all available positional

22 data, the following geo-positional strategy was adopted:

23 1. Use only positions from ARGOS satellites (T11 and T16) - these sharks provided

24 regular fixes. Shark T11 had 19 of its 23 tracked days covered by ARGOS fixes, so the

25 combined approach produced an estimated track mostly driven by ARGOS fixes. Light- 
based estimated positions, which have lower accuracy than ARGOS fixes, were very much "drowned" out by higher accuracy ARGOS fixes. In this case, the combined approach achieved interpolation among ARGOS fixes across days when there was no ARGOS fixes. Rather than interpolation within the HMM model, we used a standardized method for interpolation of all sharks with crawl (Johnson et al., 2008; Johnson and London, 2018) after estimation of tracks for each shark. Furthmore, shark T16 had 114 out of 180 or $63 \%$ tracked days covered by ARGOS fixes. In order for the HMM to converge and successfully produce an estimated track, multiple ARGOS fixes had to be sacrificed. Since the model had to reconcile the two data streams of different accuracies, a high proportion of ARGOS fixes had made the HMM struggle. Subsequently, we chose to rely only on ARGOS here because it is unclear how the reconcilation was conducted within the HMM - the detailed inner workings of the model remain opaque with limited useful published studies documenting them (https://wildlifecomputers.com/blog/usinggpe3-to-improve-geolocation-estimates). Most position fixes were flagged with location class $\mathrm{A}$ and $\mathrm{B}$, i.e., positions with unquantifiable error. However, it is established that class A and B messages can be as valuable as those of higher quality classes $(1,2,3)$ (e.g., Costa et al., 2010). We also evaluated the temporal evolution of position fixes, which showed consistency over time and presented few outliers that zig-zagged out of the overall trajectory trend.

2. Provide ARGOS positions to improve Wildlife Computers' Hidden Markov Model (HMM) for light-based geolocation (T10) - this shark had clustered but irregular ARGOS fixes. A hybrid approach was adopted by running pop-up tag's light-based information through the manufacturer's proprietary Hidden Markov Model (Wildlife Computers, 2020), with ARGOS fixes, subsampled daily, provided as known positions to help ground the model. We ran the HMM with 1, 2, 3, $4 \mathrm{~ms}^{-1}$ as the prior. Since solutions 
1 were similar throughout, we set the speed filter at $4 \mathrm{~ms}^{-1}$. This was the highest speed that

2 did not over-limit the model performance. As the HMM continued failing to converge,

3 known positions were thinned one day at a time, in order to reduce clustering, until model convergence was achieved. HMM especially struggled near the East Coast where there were abundant small-scale sea-surface temperature (SST) gradients that could have swamped the model with conflicting signals. from the shelf break.

4. No movement estimation for sharks at liberty for less than two weeks (T4, T8, T12).

Results from the above cases were down-sampled to daily positions by using the first position of the day, for any day with multiple positions. Gap filling was then done on any missing days (mostly for case 1) with the R package, crawl (Johnson et al., 2008; Johnson and London, 2018). Priors for uncertainty for both latitude and longitude were arbitrarily set at $20 \quad 0.5^{\circ}$ for ARGOS positions, since class A and B were of unknown accuracy. Similarly, priors were set at $0.25^{\circ}$ for HMM estimates which is the search grid cell size. Lastly, error estimates supplied from the Trackit model were directly input as uncertainty priors.

24 Due to errors associated with light based geolocation data, all distances calculated for sharks using light-based methods only are estimates and may not be accurate. Track length was 
1 estimated in Google Earth after plotting daily positions derived from track reconstruction

2 analysis. An estimate of the average movement rate per day was then calculated by dividing

3 track length by days at liberty. Patterns of habitat use and diel differences of G. cuvier were

4 examined after depth and temperature data archived by MiniPATs was divided into periods

5 of day and night. Due to varying day lengths along the east coast of Australia, calculations

6 were based on sunrise and sunset times at Brisbane, QLD. Utilisation of depth and preference

7 for environmental variables were examined through histogram analysis and depth behaviour

8 of individual sharks plotted in a time series over the length of deployment. Paired t-tests were

9 performed to test for significant diel differences in the average depth and temperatures

10 occupied by G. cuvier (Royer et al., 2020).

\section{Results}

13 Release condition and tag performance

14 Sixteen G. cuvier (13 female and 3 male) ranging from $157 \mathrm{~cm}$ to $384 \mathrm{~cm}$ TL (mean $252.5 \pm$ $1561.5 \mathrm{~cm}$, Table 1) were tagged with MiniPAT pop-up satellite archival tags. At the time of 16 tagging, $75 \%$ were juveniles $(157-251 \mathrm{~cm} ; 10$ females, 2 males $), 6.2 \%$ sub-adults $(284 \mathrm{~cm} ; 1$

17 male) and $18.8 \%$ were adults (330-384 cm; 3 females). Eleven of these sharks ( 9 female; 2

18 male) were also tagged with SPOT6 satellite tags (Table 1). Despite being released in a

19 healthy condition, T8 died $10 \mathrm{~d}$ after release, with the depth profile recording a constant

20 depth of $55 \mathrm{~m}$ for four consecutive days which initiated the premature release of the

21 MiniPAT. At the time of death, T8 was $\sim 34 \mathrm{~km}$ east from the southern tip of Fraser Island, $22 \mathrm{QLD}\left(25^{\circ} 47^{\prime} \mathrm{S}, 153^{\circ} 25^{\prime} \mathrm{E}\right)$ and had travelled $335 \mathrm{~km}$ (straight line distance).

24 Ten of the 16 MiniPATs deployed provided depth and temperature data, while positional 25 information was analysed for seven of those sharks (Supplementary Table S1). Track 
1 estimation was not conducted for four sharks: one shark did not report (T3) and three sharks

2 had short deployments of under 11 days (T4, T8 and T12). MiniPATs deployed on T10, T14

3 and T16 were the only MiniPATs that remained attached to the shark for their entire pre-

4 programmed deployment of $180 \mathrm{~d}$, with the remaining MiniPAT deployments shorter than

5 programmed (120-180 d), ranging from 7-140 d. Archived depth and temperature data for

6 T10 and T16 was less than the actual deployment of $180 \mathrm{~d}$, with only $166 \mathrm{~d}$ and $144 \mathrm{~d}$

7 available for analysis. After $9 \mathrm{~d}$ at liberty, the MiniPAT from T4 detached and was recovered,

8 providing the entire archived data for analysis. The MiniPAT on T3 released from the shark

9 after $8 \mathrm{~d}$, and although the tag was retrieved, no data was recorded due to unknown reasons.

10 MiniPATs from T5, T7, T9 and T15 either failed to release from the shark on the

11 programmed dates, failed to reach the surface or connect to the ARGOS system after

12 reaching the surface. The MiniPAT from T13 released after $180 \mathrm{~d}$ and washed ashore at Kirra

13 Beach in southern QLD (28 $\left.09^{\prime} \mathrm{S}, 153^{\circ} 31^{\prime} \mathrm{E}\right), \sim 277 \mathrm{~km}$ (straight line distance) from the

14 release site, where it was found by a member of the public who discarded it, preventing data

15 recovery.

\section{Horizontal movements}

18 Geolocation maps were constructed for seven sharks (Figure 1; Supplementary Figure S2),

19 with tracking between 20 and $180 \mathrm{~d}$. In the first $24 \mathrm{~h}$ post-release, six of the seven sharks 20 moved offshore, across the continental shelf edge $(>30 \mathrm{~km})$ in a general easterly direction.

21 The only shark to remain inshore over the continental shelf $(<30 \mathrm{~km})$ for $>48 \mathrm{~h}$ post-tagging

22 was T6. Regardless of the season they were tagged, most sharks moved in a northerly

23 direction from NSW to QLD waters within $15 \mathrm{~d}$ of release. Two sharks, T10 and T16, both

24 with deployments $=180 \mathrm{~d}$, returned to NSW waters during the austral spring (March, April 
1 and May) and summer (December, January and February) after $160 \mathrm{~d}$ and $179 \mathrm{~d}$ post-release,

2 respectively.

3

4 One individual (T2), remained in NSW waters for the entire $145 \mathrm{~d}$ at liberty from February to 5 July 2018 , and spent $85 \%$ of its deployment in warmer $\left(19-23{ }^{\circ} \mathrm{C}\right)$ offshore waters. T2

6 reached its most southern location $\sim 356 \mathrm{~km}$ east of Pambula, NSW (36 $\left.16^{\circ} \mathrm{S}, 153^{\circ} 54^{\prime} \mathrm{E}\right)$ in

7 April (austral autumn), but by July (austral winter) returned to inshore waters off NSW , 90

$8 \mathrm{~km}$ north of its tagging location. Shark T1, tagged on the same day at the same location,

9 remained on the continental shelf for $86 \%$ of its deployment, with $4 \mathrm{~d}$ spent off the

10 continental shelf edge within the first week after tagging (Figure 1). Of the six sharks that

11 transited north into QLD waters, all swam either along the shelf edge or in offshore waters.

12

13 The greatest distance travelled was by T10, covering $\sim 6937 \mathrm{~km}$ (straight line distance) in $14180 \mathrm{~d}\left(\sim 39 \mathrm{~km} \mathrm{day}^{-1}\right)$, between Newcastle, NSW (32 $\left.55^{\prime} \mathrm{S}, 151^{\circ} 47^{\prime} \mathrm{E}\right)$ (Figure 1), and the 15 Whitsunday Islands off the coast of Mackay, QLD. Shark T6 made the most substantial move 16 north eastward ( 1030 km straight line distance) from Coffs Harbour, NSW into the waters 17 of New Caledonia $\sim 650 \mathrm{~km}$ west of the mainland (Figure 1). Post tagging, T16 moved north and offshore to the Great Barrier Reef in $<1$ month, then spent 3 months and $43 \%$ of its deployment on and surrounding Lihou Reef ( $\left.17^{\circ} 24^{\prime} \mathrm{S}, 151^{\circ} 40^{\prime} \mathrm{E}\right)$ adjacent to Cairns, QLD. During its $20 \mathrm{~d}$ at liberty, T11 displayed the highest movement rate at $61.5 \mathrm{~km}^{\mathrm{day}}{ }^{-1}$, travelling $\sim 1235 \mathrm{~km}$ north from Coffs Harbour, NSW, maintaining a path throughout the Tasman Basin, over the Queensland, Brisbane and Recorder Seamounts until it reached the southern Coral Sea $\left(23^{\circ} 44^{\prime} \mathrm{S}, 154^{\circ} 4^{\prime} \mathrm{E}\right)$. A similar northerly offshore route was also undertaken by T14 and T16 after tagging in the austral winter (June, July and August), with both sharks traversing near the Brisbane, Moreton and Recorder Seamounts. T16 continued 
1 on this north east path over the Fraser Seamount before entering the Cato Trough in the Coral

2 Sea ( $\left.154^{\circ} 54^{\prime} \mathrm{S}, 23^{\circ} 20^{\prime} \mathrm{E}\right)$. Overall, broad-scale horizontal movement differed greatly among 3 conspecifics.

5 Depth, temperature and vertical habitat use

6 Tagged G. cuvier spent considerable time at, or within $1 \mathrm{~m}$ of the surface (depths recorded 7 above $0 \mathrm{~m}$ were omitted from analysis). Overall, $71 \%$ of time was spent within $50 \mathrm{~m}$ of the 8 surface, and $96 \%$ of time in the upper $100 \mathrm{~m}$ of the water column (Figure $2 \mathrm{a}$ ). Time spent in

9 the mixed layer varied among individuals and ranged from $46.1 \%$ to $93.1 \%$ (Table 2).

10 Maximum depths varied among individual sharks and ranged from 92-904 m (Table 2). Only

11 three sharks (T1, T4 and T8) did not dive below $200 \mathrm{~m}$ (Figure 3), yet depths used by T1

12 were unlikely constrained by bathymetry as time was spent in waters beyond the continental

13 shelf edge. Shark T4, at liberty for 9 days, recorded the lowest mean depth $(10.2 \mathrm{~m} \pm 0.03$

14 SE) and used the upper $30 \mathrm{~m}$ of the water column more than any other of the tagged sharks 15 (Table 2).

17 Mean depth $(37.19 \mathrm{~m} \pm 0.38 \mathrm{SE})$ and temperature $\left(23.42{ }^{\circ} \mathrm{C} \pm 0.02 \mathrm{SE}\right)$ varied among sharks

18 (Table 2). No significant difference was evident in use of depth and temperatures,

19 irrespective of day or night (paired $t$-test, depth: $t=0.44, n=10, p>0.05$, temperature: $t=$ $200.35, n=10, p>0.05)$. Cumulative time-at-temperature data indicated tagged G. cuvier spent 21 most of the daylight hours in water temperatures between 24 and $25^{\circ} \mathrm{C}$, with little variation 22 between day and night. (Figure 2b). Water temperatures occupied by tagged G. cuvier 23 ranged from $6.7-28.9^{\circ} \mathrm{C}$, with $70.2 \%$ of the time between 22 and $25^{\circ} \mathrm{C}$. Temperatures $<16$ $24{ }^{\circ} \mathrm{C}$ were infrequently occupied, with the minimum temperature of $6.7^{\circ} \mathrm{C}$ during the deepest 25 dive by $\mathrm{T} 2$ at $784.5 \mathrm{~m}$. 
2 Diving behaviour differed among conspecifics. For example, depth profiles revealed

3 oscillatory diving behaviour in T2 (Figure $4 \mathrm{a}$ ), which was characterised by $\sim 1$ brief dive per

4 hour to $100-300 \mathrm{~m}$, with consistent returns to the surface. This pattern was also evident in

5 T6, yet occurred more frequently at $\sim 3$ dives per hour (Figure 4b). Sharks T2, T6, T11 and

6 T14 made infrequent dives into the mesopelagic zone to depths of 400-800 m (Figure 3).

7 Each of these deep dives lasted between 40-60 min, concluding with the shark returning to

8 the top $20 \mathrm{~m}$ of the water column. Shark T11 completed the deepest dive to $904 \mathrm{~m}$, with the

9 descent from, and ascent to the surface taking approximately $40 \mathrm{~min}$ (Figure 4c). Other deep

10 dives performed by T2, T6, T11 and T14 occurred throughout the day and night, with no diel

11 pattern evident.

\section{Discussion}

14 This study describes habitat use of G. cuvier throughout temperate, sub-tropical and tropical

15 waters of eastern Australia. It confirms previous work demonstrating that, although typically

16 found in warm tropical waters, this species also inhabits warmer temperate regions (Holmes

17 et al., 2014; Ferreira et al., 2015). Individual movements varied regardless of season, with all

18 but one shark moving north into warmer QLD waters after tagging. Similarities among sharks

19 in broad-scale movement patterns were evident, with a preference for offshore oceanic

20 habitats. The use of offshore waters beyond the continental shelf edge was often

21 characterised by long-distance directional movement $>100 \mathrm{~km}$, with frequent travel over

22 seamounts within the Tasman Basin in the western Pacific Ocean. These broad-scale

23 movements using predominantly offshore waters are consistent with earlier studies (Holmes

24 et al., 2014; Werry et al., 2014) and highlight the connectivity between tropical and warm

25 temperate regions in eastern Australia. 
2 Increased movement over the continental shelf by sharks was observed during the austral

3 spring and summer. Ocean currents, water temperature and prey distribution are known

4 drivers of shark movement (Heupel et al., 2015; Andrzejaczek et al., 2018) and likely

5 influenced this move from offshore waters. On the east coast of Australia, the East Australian

6 Current brings warmer water nearer the coastline during summer months and encroaches onto

7 the continental shelf (Ridgway and Godfrey, 1997). Areas where the continental shelf

8 narrows generally see upwelling of nutrient-rich water (south of $28.5^{\circ} \mathrm{S}$ and $31^{\circ} \mathrm{S}$ ), thus

9 increasing primary productivity (Everett et al., 2014). This change in movement is observed

10 by Papastamatiou et al. (2013), who found higher chlorophyll $a$ concentrations and warm

11 ocean temperatures $\left(23-26^{\circ} \mathrm{C}\right)$ were also attributed to change in movement of G. cuvier

12 around the Hawaiian Islands. Together, warmer water during summer, in combination with

13 higher productivity could serve as an indicator for increased presence of G. cuvier in inshore

14 and coastal waters.

16 Tagged sharks displayed a preference for water between $22-25^{\circ} \mathrm{C}$, similar to previous

17 studies (Holmes et al., 2014; Ferreira et al., 2015). Decreased temperatures were occupied

18 infrequently during deep dive excursions, confirming that Galeocerdo cuvier are capable of

19 withstanding a much broader temperature range $\left(4-31.2{ }^{\circ} \mathrm{C}\right)$. However, it is unlikely that

20 these temperatures could be sustained for long periods. Cold tolerance has been documented

21 by the occasional catch of conspecifics in Icelandic waters (Matsumoto et al., 2005), and in

22 the Tasman Sea (Holmes et al., 2014) and supports the movement south into higher latitudes 23 observed in this study. 
1 Sharks in this study often moved near seamounts in the Tasman Basin on their transit north

2 during the austral autumn and winter, indicating that the oceanographic conditions and prey

3 availability at these locations might play a role in driving seasonal offshore movement

4 (Holmes et al., 2014; Werry et al., 2014). Indeed, the seasonal variability in physical

5 conditions at seamounts influences their use by many other species of shark (Oliver et al.,

6 2011; Barnett et al., 2012), pelagic fish (Morato et al., 2010) and turtles (Santos et al., 2007).

7 These unique areas of high biodiversity, and therefore food resource availability, may

8 influence the movement of G. cuvier to off-shelf habitats as observed in this study. The

9 findings of Ajemian et al. (2020) support this use of deeper offshore waters, although their

10 observations were for sub-adult and adult G. cuvier, a higher use of off-shelf waters during

11 autumn and winter months was documented.

12

13 The distances travelled between northern QLD to southern NSW demonstrate the broad

14 latitudinal range that G. cuvier covered along the east coast of Australia. Large-scale

15 movements are not uncommon for G. cuvier and distances travelled by T10 ( $\sim 6937)$ and T16

$16(\sim 6257 \mathrm{~km})$ are consistent with previous studies (Holmes et al., 2014; Heithaus et al., 2007).

17 Other shark species, e.g. bull sharks, Carcharhinus leucas $(\sim 1770 \mathrm{~km})$ and white sharks,

18 Carcharodon carcharias ( 40 $000 \mathrm{~km})$ have also exhibited similar dispersal behaviour along

19 the east coast and into international waters (Heupel et al., 2015; Spaet et al., 2020a, Spaet et

20 al. 2020b). The extensive movements performed by G. cuvier highlight the need for multi-

21 jurisdictional management among Australian states in regard to shark mitigation measures,

22 conservation strategies and fisheries management.

24 Highly directional swimming was observed in most sharks and was often interspersed with 25 localised movements over a smaller spatial scale $(<35 \mathrm{~km})$. This behaviour was particularly 
1 evident in individuals with longer deployments when they reached the Great Barrier Reef,

2 QLD throughout the austral winter and spring. Specifically, localised movements occurred

3 for 71 days (over $\sim 30 \mathrm{~km}$ ) for T16 as it moved around Lihou Reef $\left(17^{\circ} 24^{\prime} \mathrm{S}, 151^{\circ} 40^{\prime} \mathrm{E}\right)$

4 (Figure 1). This behaviour could be attributed to resource availability and foraging and could

5 potentially be linked to the nesting of green turtles, Chelonia mydas during October to April

6 (Department of Environment and Energy, 2017). Seasonal availability of a particular

7 resource, e.g. sea turtles has been exploited by tiger sharks (Fitzpatrick et al., 2012; Acuña-

8 Marrero et al., 2017). Extended tag deployments and a larger sample size of tagged animals

9 could illuminate on potential residency patterns.

10

11 The infrequent utilisation of deeper oceanic waters, $>600 \mathrm{~m}$, by three G. cuvier was

12 associated with their horizontal movement off the Australian continental shelf and consisted

13 of a brief but fast, near-vertical descent with an immediate, but slower return to the surface.

14 Previous studies suggest that deep-diving behaviour in G. cuvier is a means for navigation,

15 with the use of topography and bathymetric features providing orientation between locations

16 during broad-scale movement (Holland et al., 1999; Holmes et al., 2014). Although difficult

17 to quantify, the use of brief, deep dives for orientation has been recorded in both $C$.

18 carcharias and shortfin mako sharks, Isurus oxyrinchus, during migrations (Francis et al.,

19 2012; Rogers et al., 2015). A similar dive profile, describing powered descents was described

20 by Nakamura et al. (2011) in G. cuvier tagged in Hawaii and has also been observed in $I$.

21 oxyrinchus (Sepulveda et al., 2004). Originally, Weihs (1973) predicted that negatively

22 buoyant fish would perform a gliding motion with a shallow angle upon descent, to conserve

23 energy. This theory proved correct for some predatory fishes (Andrzejaczek et al., 2019b).

24 However, was inconsistent with the characteristic rapid vertical descent observed in previous 
1 studies of G. cuvier, with navigation and foraging more likely explanations for the deep

2 diving behaviour (Nakamura et al., 2011; Holmes et al., 2014).

4 Oscillatory diving behaviour was observed in two sharks within this study, a pattern of diving

5 also documented in other shark species (Sepulveda et al., 2004: Spaet et al., 2017). Patterns

6 differed slightly between the two sharks, yet were characterised by distinct repetitive near-

7 vertical descents and a short time spent at depth, followed by a near-vertical ascent to the

8 upper water column. These dive patterns are consistent with movement often attributed to

9 foraging and prey detection in G. cuvier of benthic and surface prey (Nakmura et al., 2011;

10 Heithaus et al., 2002). A similar observation was made by Carey et al. (1990) and Campana

11 et al. (2011) in P. glauca, with oscillatory dives repeated every few hours. Campana et al.

12 (2011) speculated that these dives are likely a strategy employed to increase foraging

13 potential and efficiency and reduce metabolic losses that occur when remaining in warm

14 surface waters during the day. Furthermore, the most recent study by Andrzejaczek et al.

15 (2020) surmises that G. cuvier oscillatory diving patterns reduce energy output when

16 compared to horizontal swimming and can provide a cost-efficient foraging strategy.

17 Although thermoregulation has been previously reported as the purpose for oscillatory diving

18 in several shark species (Thums et al., 2013; Carey et al., 1990), conspecifics in this study

19 did not display the same oscillatory diving behaviour. Therefore, it is likely that the vertical

20 patterns observed in this study indicate energy conservation and prey searching by

21 individuals.

23 This study examines the highly dynamic and complex habitat use by G. cuvier off eastern

24 Australia through the combined use of satellite and archival technology. Variation among 25 conspecifics existed in both broad-scale horizontal movement and vertical habitat use, and 
1 was likely associated with navigation, resource availability, foraging, energy conservation

2 and fluctuations in water temperature. Movement to lower latitudes coincided with

3 decreasing water temperature at mid-latitudes and while thermal conditions may influence

4 horizontal movement, a tolerance for cooler water was evident through intermittent use of

5 water below the thermal preference of $22-25{ }^{\circ} \mathrm{C}$. Increased cross-shelf activity was observed

6 during the austral spring and summer which coincided with a strengthening EAC, warmer

7 water temperature and changes in prey distribution. Yet, it was evident that despite being

8 associated with coastal waters and captured and released relatively close to shore, G. cuvier

9 spent majority of time in waters off the continental shelf. To better understand the varied and

10 extensive movements documented in this study, long-term movement patterns and the

11 influence of environmental drivers should be investigated.

12

13 Supplementary material

14 The following supplementary material is available at ICESJMS online.

15

16

Table S1. Geolocation input, methods and SPOT Location Class (LC) fixes used to create most probable tracks for seven tagged Galeocerdo cuvier.

Figure S2. Most probable tracks with error ellipses (grey shaded areas) of seven tagged Galeocerdo cuvier reconstructed using positions from ARGOS and light-based geolocation to provide daily positions. All maps were generated using the marmap package in R (Pante \& Simon-Bouhe 2013).

Acknowledgements

Primary project funding and support was provided by the New South Wales Department of

26 Primary Industries (NSW DPI), Australia through the Shark Management Strategy. Southern

27 Cross University provided funding towards an honours project to R Lipscombe. We would

28 like to thank contracted SMART drumline fishers from Ballina and Evans Head for their 29 assistance with this project. 
1 RSL conducted fieldwork and wrote the manuscript, JLYS and CHL analysed horizontal

2 data, reconstructed tracks and edited the manuscript, AS edited the manuscript, CPB

3 conducted fieldwork, PAB designed the study, conducted fieldwork and edited the

4 manuscript.

5

6 Data Availability Statement

7 The data underlying this article will be shared on reasonable request to the corresponding

8 author.

9

10

11

12

13

14

15

16

17

18

19

20

\section{References}

Acuña-Marrero, D., Smith, A. N., Hammerschlag, N., Hearn, A., Anderson, M. J., Calich, H., and Salinas-de-León, P. 2017. Residency and movement patterns of an apex predatory shark (Galeocerdo cuvier) at the Galapagos Marine Reserve. PLoS One, 12: e0183669.

Afonso, A. S., and Hazin, F. H. 2015. Vertical movement patterns and ontogenetic niche expansion in the tiger shark, Galeocerdo cuvier. PLoS One, 10: e0116720.

Ajemian, M. J., Drymon, J. M., Hammerschlag, N., Wells, R. D., Street, G., Falterman, B., McKinney, J.A., et al. 2020. Movement patterns and habitat use of tiger sharks (Galeocerdo cuvier) across ontogeny in the Gulf of Mexico. PloS One, 15: e0234868

Andrzejaczek, S., Gleiss, A. C., Jordan, L. K., Pattiaratchi, C. B., Howey, L. A., Brooks, E. J., and Meekan, M. G. 2018. Temperature and the vertical movements of oceanic whitetip sharks, Carcharhinus longimanus. Scientific Reports, 8: 1-12.

Andrzejaczek, S., Gleiss, A. C., Lear, K. O., Pattiaratchi, C. B., Chapple, T. K., and Meekan, M. G. 2019a. Biologging tags reveal links between fine-scale horizontal and vertical movement behaviors in tiger sharks (Galeocerdo cuvier). Frontiers in Marine Science, 6:113.

Andrzejaczek, S., Gleiss, A. C., Pattiaratchi, C. B., and Meekan, M. G. 2019b. Patterns and drivers of vertical movements of the large fishes of the epipelagic. Reviews in Fish Biology and Fisheries, 29: 335-354.

Andrzejaczek, S., Gleiss, A. C., Lear, K. O., Pattiaratchi, C., Chapple, T. K., and Meekan, M. G. 2020. Depth-dependent dive kinematics suggest cost-efficient foraging strategies by tiger sharks. Royal Society Open Science, 7: 1-14.

Barnes, C. J., Butcher, P. A., Macbeth, W. G., Mandelman, J. W., Smith, S. D., and Peddemors, V. M. 2016. Movements and mortality of two commercially exploited 
carcharhinid sharks following longline capture and release off eastern Australia. Endangered Species Research, 30: 193-208.

Barnett, A., Abrantes, K. G., Seymour, J., and Fitzpatrick, R. 2012. Residency and spatial use by reef sharks of an isolated seamount and its implications for conservation. PloS One, 7: e36574.

Butcher, P. A., Piddocke, T. P., Colefax, A. P., Hoade, B., Peddemors, V. M., Borg, L., and Cullis, B.R. 2020. Beach safety: can drones provide a platform for sighting sharks?. Wildlife Research, 46: 701-712.

11

Butcher, P. A., Peddemors, V. M., Mandelman, J. W., McGrath, S. P., and Cullis, B. R. 2015. At-vessel mortality and blood biochemical status of elasmobranchs caught in an Australian commercial longline fishery. Global Ecology and Conservation, 3: 878-889.

Campana, S. E., Dorey, A., Fowler, M., Joyce, W., Wang, Z., Wright, D., and Yashayaev, I. 2011. Migration pathways, behavioural thermoregulation and overwintering grounds of blue sharks in the Northwest Atlantic. PloS One, 6: e16854.

Carey, F. G., Scharold, J. V., and Kalmijn, A. J. 1990. Movements of blue sharks (Prionace glauca) in depth and course. Marine biology, 106: 329-342.

Colefax, A. P., Butcher, P. A., Pagendam, D. E., and Kelaher, B. P. 2019. Reliability of marine faunal detections in drone-based monitoring. Ocean \& Coastal Management, 174: $108-115$.

Costa, D. P., Robinson, P. W., Arnould, J. P. Y., Harrison, A. L., Simmons, S. E., et al. 2010. Accuracy of ARGOS locations of pinnipeds at-sea estimated using Fastloc GPS. PLoS One, 5: e8677.

CLS. 2011. Argos Users Manual. http://www.argos-system.org. (Last accessed 10 Apr 2019).

Department of Environment and Energy. 2011. 'Recovery Plan for Marine Turtles in Australia, Commonwealth of Australia 2017'. Retreived from https://www.environment.gov.au/system/files/resources/46eedcfc-204b-43de-99c54d6f6e72704f/files/recovery-plan-marine-turtles-2017.pdf. (Last accessed 12 May 2020).

Everett, J. D., Baird, M. E., Roughan, M., Suthers, I. M., and Doblin, M. A. 2014. Relative impact of seasonal and oceanographic drivers on surface chlorophyll a along a Western Boundary Current. Progress in Oceanography, 120: 340-351.

Ferreira, L. C., Simpfendorfer, C. 2019. Galeocerdo cuvier. The IUCN Red List of Threatened Species 2019: e.T39378A2913541. https://dx.doi.org/10.2305/IUCN.UK.20191.RLTS.T39378A2913541.en. (Last accessed 12 May 2020).

Ferreira, L. C., Thums, M., Meeuwig, J. J., Vianna, G. M., Stevens, J., McAuley, R., and Meekan, M. G. 2015. Crossing latitudes-long-distance tracking of an apex predator. PLoS One, 10: e0116916. 
Fitzpatrick, R., Thums, M., Bell, I., Meekan, M. G., Stevens, J. D., and Barnett, A. 2012. A comparison of the seasonal movements of tiger sharks and green turtles provides insight into their predator-prey relationship. PLoS One, 7: e51927.

Francis, M. P., Shivji, M. S., Duffy, C. A., Rogers, P. J., Byrne, M. E., Wetherbee, B. M., Tindale, S. C. et al. 2019. Oceanic nomad or coastal resident? Behavioural switching in the shortfin mako shark (Isurus oxyrinchus). Marine Biology, 166: 1-16.

Field, I. C., Meekan, M. G., Buckworth, R. C., and Bradshaw, C. J. 2009. Protein mining the world's oceans: Australasia as an example of illegal expansion-and-displacement fishing. Fish and Fisheries, 10: 323-328.

Fraser-Baxter, S., and Medvecky, F. 2018. Evaluating the media's reporting of public and political responses to human-shark interactions in NSW, Australia. Marine Policy, 97: 109118.

Galuardi, B., and Lam, C. H. 2014. Telemetry analysis of highly migratory species. In Stock Identification Methods, pp. 447-476. Academic Press, London. UK.

19

Guyomard, D., Perry, C., Tournoux, P. U., Cliff, G., Peddemors, V., and Jaquemet, S. 2019. An innovative fishing gear to enhance the release of non-target species in coastal sharkcontrol programs: the SMART (shark management alert in real-time) drumline. Fisheries Research, 216: 6-17.

Heithaus, M., Dill, L., Marshall, G., and Buhleier, B. 2002. Habitat use and foraging behavior of tiger sharks (Galeocerdo cuvier) in a seagrass ecosystem. Marine Biology, 140: 237-248.

Heithaus, M. R., Wirsing, A. J., Dill, L. M., and Heithaus, L. I. 2007. Long-term movements of tiger sharks satellite-tagged in Shark Bay, Western Australia. Marine Biology, 151: 14551461 .

Heupel, M. R., Simpfendorfer, C. A., Espinoza, M., Smoothey, A. F., Tobin, A., and Peddemors, V. 2015. Conservation challenges of sharks with continental scale migrations. Frontiers in Marine Science, 2: 1-7.

Holland, K. N., Wetherbee, B. M., Lowe, C. G., and Meyer, C. G. 1999. Movements of tiger sharks (Galeocerdo cuvier) in coastal Hawaiian waters. Marine Biology, 134: 665-673.

Holmes, B. J., Pepperell, J. G., Griffiths, S. P., Jaine, F. R., Tibbetts, I. R., and Bennett, M. B. 2014. Tiger shark (Galeocerdo cuvier) movement patterns and habitat use determined by satellite tagging in eastern Australian waters. Marine Biology, 161: 2645-2658.

Holmes, B. J., Sumpton, W. D., Mayer, D. G., Tibbetts, I. R., Neil, D. T., and Bennett, M. B. 2012. Declining trends in annual catch rates of the tiger shark (Galeocerdo cuvier) in Queensland, Australia. Fisheries Research, 129: 38-45.

Johnson, D. S., London, J. M., Lea, M. A., and Durban, J. W. 2008. Continuous-time correlated random walk model for animal telemetry data. Ecology, 89: 1208-1215. 
Johnson, D., and London, J. 2018. Crawl: an R package for fitting continuous-time correlated random walk models to animal movement data. Zenodo.

Kohler, N. E., and Turner, P. A. 2001. Shark tagging: a review of conventional methods and studies. In The behavior and sensory biology of elasmobranch fishes: an anthology in memory of Donald Richard Nelson, pp. 191-224. Springer, Dordrecht, Netherlands.

Lam, C. H., Nielsen, A., and Sibert, J. R. 2010. Incorporating sea-surface temperature to the light-based geolocation model TrackIt. Marine Ecology Progress Series, 419: 71-84.

10

Macbeth, W. G., Geraghty, P. T., Peddemors, V. M., and Gray, C. A. 2009. 'Observer-based study of targeted commercial fishing for large shark species in waters off northern New South Wales.' Cronulla Fisheries Research Centre of Excellence, Industry and Investment NSW, Cronulla, Australia.

Matsumoto, T., Saito, H., and Miyabe, N. 2005. Report of observer program for Japanese tuna longline fishery in the Atlantic Ocean from August 2003 to January 2004. Collective Volumes of Scientific Papers, ICCAT, 58: 1694-1714.

McPhee, D. 2014. Unprovoked shark bites: are they becoming more prevalent? Coastal Management, 42: 478-492.

Morato, T., Hoyle, S. D., Allain, V., and Nicol, S. J. 2010. Seamounts are hotspots of pelagic biodiversity in the open ocean. Proceedings of the National Academy of Sciences, 107: 9707-9711.

Nakamura, I., Watanabe, Y. Y., Papastamatiou, Y. P., Sato, K., and Meyer, C. G. 2011. Yoyo vertical movements suggest a foraging strategy for tiger sharks Galeocerdo cuvier. Marine Ecology Progress Series, 424: 237-246.

Nielsen, A., and Sibert, J. R. 2007. State-space model for light-based tracking of marine animals. Canadian Journal of Fisheries and Aquatic Science, 64: 1055-1068.

Oliver, S. P., Hussey, N. E., Turner, J. R., and Beckett, A. J. 2011. Oceanic sharks clean at coastal seamount. PLoS One, 6: e14755.

Pante, E., and Simon-Bouhe, B. 2013. Marmap: a package for importing, plotting and analyzing bathymetric and topographic data in R. PLoS One, 8: e73051.

Papastamatiou, Y. P., Meyer, C. G., Carvalho, F., Dale, J. J., Hutchinson, M. R., and Holland, K. N. 2013. Telemetry and random-walk models reveal complex patterns of partial migration in a large marine predator. Ecology, 94: 2595-2606.

Reid, D., Robbins, W., and Peddemors, V. 2011. Decadal trends in shark catches and effort from the New South Wales, Australia, Shark Meshing Program 1950-2010. Marine and Freshwater Research, 62: 676-693 
Ridgway, K., and Godfrey, J. 1997. Seasonal cycle of the East Australian current. Journal of

Rogers, P. J., Huveneers, C., Page, B., Goldsworthy, S. D., Coyne, M., Lowther, A. D., Mitchell, J. G. et al. 2015. Living on the continental shelf edge: habitat use of juvenile shortfin makos Isurus oxyrinchus in the Great Australian Bight, southern Australia. Fisheries Oceanography, 24: 205-218.

Royer, M., Maloney, K., Meyer, C., Cardona, E., Payne, N., Whittingham, K., Silva, G., et al. 2020. Scalloped hammerhead sharks swim on their side with diel shifts in roll magnitude and periodicity. Animal Biotelemetry, 8: 1-12.

Santos, M. A., Bolten, A. B., Martins, H. R., Riewald, B., and Bjorndal, K. A. 2007. Airbreathing visitors to seamounts: sea turtles. In Seamounts: Ecology, Fisheries and Conservation. Fisheries and Aquatic Resource Series, pp. 239-244. Blackwell Scientific, Oxford, UK.

Sepulveda, C. A., Kohin, S., Chan, C., Vetter, R., and Graham, J. B. 2004. Movement patterns, depth preferences, and stomach temperatures of free-swimming juvenile mako sharks, Isurus oxyrinchus, in the Southern California Bight. Marine Biology, 145: 191-199.

Simmons, P., and Mehmet, M. I. 2018. Shark management strategy policy considerations: community preferences, reasoning and speculations. Marine Policy, 96: 111-119.

Spaet, J. L.Y., Lam, C. H., Braun, C. D., and Berumen, M. L. 2017. Extensive use of mesopelagic waters by a Scalloped hammerhead shark (Sphyrna lewini) in the Red Sea. Animal Biotelemetry, 5: 1-12.

Spaet, J. L. Y., Patterson, T. A., Bradford, R. W., and Butcher, P. A. 2020a. Spatiotemporal distribution patterns of immature Australasian white sharks (Carcharodon carcharias). Scientific Reports, 10: 1-13.

Spaet, J. L. Y., Manica, A., Brand, C. P., Gallen, C., Butcher P. A. 2020b. Environmental influences driving the occurrence of juvenile and subadult white sharks (Carcharodon carcharias) along the Australian east coast. Marine Ecology Progress Series, (in press).

Speed, C. W., O’Shea, O. R., and Meekan, M. G. 2013. Transmitter attachment and release methods for short-term shark and stingray tracking on coral reefs. Marine Biology, 160: 1041-1050.

Thums, M., Meekan, M., Stevens, J., Wilson, S., and Polovina, J. 2013. Evidence for behavioural thermoregulation by the world's largest fish. Journal of the Royal Society Interface, 10: 1-5.

Weihs, D. 1973. Mechanically efficient swimming techniques for fish with negative buoyancy. Journal of Marine Research, 31: 194-209.

Werry, J. M., Planes, S., Berumen, M. L., Lee, K. A., Braun, C. D., and Clua, E. 2014. Reeffidelity and migration of tiger sharks, Galeocerdo cuvier, across the Coral Sea. PloS One, 9: e83249. 


\section{Computers Data Portal User Guide (static.wildlifecomputers.com/Location-Processing-} 7 UserGuide.pdf). Accessed 1 February 2020.

Whitney, N. M. and Crow, G. L. 2007. Reproductive biology of the tiger shark (Galeocerdo cuvier) in Hawaii. Marine Biology, 151: 63-70.

Wildlife Computers. 2020. Location Processing (GPE3 \& Fastloc ${ }^{\circledR}$ ) in the Wildlife 8

9 Williams, A., Upston, J., Green, M., and Graham, K. 2016. Selective commercial line fishing 10 and biodiversity conservation co-exist on seamounts in a deepwater marine reserve. Fisheries 11 Research, 183: 617-624. 


\section{Figures}

2

3 Figure 1. Most probable tracks of seven tagged Galeocerdo cuvier reconstructed using 4 positions from ARGOS and light-based geolocation to provide daily positions. All maps were 5 generated using the marmap package in R (Pante \& Simon-Bouhe 2013).

6

Figure 2. Time spent $( \pm \mathrm{SE})$ during day (white bars) and night (black bars) at a) depth (50 m bins), and b) temperature $\left(2^{\circ} \mathrm{C}\right.$ bins $)$ for 10 MiniPAT tagged Galeocerdo cuvier.

Figure 3. Depth profiles for 10 MiniPAT tagged Galeocerdo cuvier produced using summary 11 data sampled at 5 min intervals (summary data was used for all sharks except T4 where data 12 was sampled at 3 second intervals providing the entire archive).

13

14 Figure 4. Examples of diving behaviour from three MiniPAT tagged Galeocerdo cuvier 15 depicting a) oscillatory diving of $\mathrm{T} 2$ on day $67, \mathrm{~b}$ ) oscillatory diving of T6 on day 7 , and c) a 16 deep dive of T11 on day 1 . Profiles were produced using summary data sampled at $5 \mathrm{~min}$ 17 intervals 
Tables

Table 1. Summary of biological details, tag deployment and tracking data for 16 Galeocerdo cuvier tagged off the mid-north coast of eastern Australia. Note * T13 detached after $180 \mathrm{~d}$ but the tag was found by a member of the public who subsequently discarded the tag, preventing data recovery.

\begin{tabular}{|c|c|c|c|c|c|c|c|c|c|}
\hline ID & Sex & $\begin{array}{l}\text { Total length } \\
\text { (cm) }\end{array}$ & $\begin{array}{l}\text { Tagging } \\
\text { date }\end{array}$ & $\begin{array}{c}\text { Tagging location } \\
\text { Lat. }\left({ }^{\circ} \mathrm{S}\right) \text {, Long. }\left({ }^{\circ} \mathrm{E}\right)\end{array}$ & Tag type & Date detached & Days tracked & $\begin{array}{l}\text { Track length } \\
(\mathbf{k m})\end{array}$ & $\begin{array}{c}\text { Average } \\
\text { movement } \\
\left(\mathrm{km} \mathrm{day}^{-1}\right)\end{array}$ \\
\hline T1 & $\mathrm{F}$ & 188 & $13 / 02 / 2018$ & $30.279,153.203$ & SPOT, MiniPAT, acoustic & $19 / 03 / 2018$ & 34 & 926 & 26.5 \\
\hline $\mathbf{T} 2$ & $\mathrm{~F}$ & 242 & $13 / 02 / 2018$ & $30.290,153.169$ & SPOT, MiniPAT, acoustic & 07/08/2018 & 145 & 3726 & 25.7 \\
\hline T 3 & $\mathrm{~F}$ & 229 & $23 / 01 / 2019$ & $28.855,153.612$ & MiniPAT, acoustic & $30 / 01 / 2019$ & - & - & - \\
\hline $\mathbf{T} 4$ & $\mathrm{~F}$ & 234 & $23 / 01 / 2019$ & $29.589,153.264$ & MiniPAT, acoustic & $02 / 02 / 2019$ & 9 & - & - \\
\hline T 5 & M & 248 & $25 / 01 / 2019$ & $30.323,153.179$ & MiniPAT, acoustic & - & - & - & - \\
\hline T 6 & $\mathrm{~F}$ & 251 & 29/03/2019 & $30.323,153.180$ & SPOT, MiniPAT, acoustic & $19 / 05 / 2019$ & 51 & 2563 & 50.3 \\
\hline $\mathbf{T} 7$ & $\mathrm{~F}$ & 216 & 29/03/2019 & $30.323,153.180$ & SPOT, MiniPAT, acoustic & - & - & - & - \\
\hline T 8 & $\mathrm{~F}$ & 223 & $24 / 04 / 2019$ & $28.813,153.613$ & SPOT, MiniPAT, acoustic & 09/05/2019 & 10 & - & - \\
\hline T 9 & M & 157 & $08 / 05 / 2019$ & $30.228,153.179$ & SPOT, MiniPAT, acoustic & 20/10/2019 & - & - & - \\
\hline T 10 & $\mathrm{~F}$ & 236 & $08 / 05 / 2019$ & $30.237,153.184$ & SPOT, MiniPAT, acoustic & $04 / 11 / 2019$ & 180 & 6937 & 38.5 \\
\hline T 11 & M & 284 & $09 / 05 / 2019$ & $30.328,153.151$ & SPOT, MiniPAT, acoustic & $01 / 06 / 2019$ & 21 & 1235 & 61.5 \\
\hline T 12 & $\mathrm{~F}$ & 228 & $14 / 05 / 2019$ & $30.317,153.147$ & SPOT, MiniPAT, acoustic & $26 / 05 / 2019$ & 8 & - & - \\
\hline T 13* & $\mathrm{F}$ & 212 & $14 / 05 / 2019$ & $30.322,153.180$ & MiniPAT, acoustic & - & - & - & - \\
\hline T 14 & $\mathrm{~F}$ & 354 & $11 / 06 / 2019$ & $28.827,153.595$ & MiniPAT, acoustic & $13 / 12 / 2019$ & 180 & 3342 & 18.5 \\
\hline T 15 & $\mathrm{~F}$ & 384 & 09/07/2019 & $28.837,153.615$ & SPOT, MiniPAT, acoustic & - & - & - & - \\
\hline T 16 & $\mathrm{~F}$ & 330 & $23 / 07 / 2019$ & $28.872,153.604$ & SPOT, MiniPAT, acoustic & $23 / 01 / 2020$ & 180 & 6257 & 33.9 \\
\hline
\end{tabular}


Table 2. Galeocerdo cuvier depth, water temperature and time spent in mixed layer (0-193 m) archived by MiniPAT pop-up satellite tags $(n=10)$.

\begin{tabular}{cccccc}
\hline \multirow{2}{*}{$\begin{array}{c}\text { Shark } \\
\text { ID }\end{array}$} & Min-Max & Mepth $(\mathbf{m})$ & \multicolumn{2}{c}{ Temperature $\left({ }^{\circ} \mathbf{C}\right)$} & Mixed layer $(\%)$ \\
\hline T1 & $1.0-173.0$ & $36.9 \pm 0.36$ & $15.6-27.5$ & $23.4 \pm 0.05$ & 46.1 \\
T2 & $0.0-784.5$ & $29.3 \pm 0.22$ & $6.7-28.0$ & $22.7 \pm 0.01$ & 78.5 \\
T4 & $0.0-92.0$ & $10.2 \pm 0.03$ & $17.8-27.2$ & $23.2 \pm 0.01$ & 93.1 \\
T6 & $0.5-755.0$ & $46.8 \pm 0.56$ & $7.0-27.2$ & $23.9 \pm 0.02$ & 78.6 \\
T8 & $0.5-150.0$ & $44.9 \pm 0.41$ & $15.6-25.8$ & $24.1 \pm 0.03$ & 75.6 \\
T10 & $1.0-255.0$ & $20.7 \pm 0.22$ & $15.3-24.8$ & $22.0 \pm 0.01$ & 85.4 \\
T11 & $1.0-904.0$ & $36.6 \pm 0.71$ & $6.8-25.6$ & $24.3 \pm 0.01$ & 92.7 \\
T12 & $0.5-276.0$ & $27.9 \pm 0.40$ & $15.4-24.5$ & $22.6 \pm 0.02$ & 74.0 \\
T14 & $0.5-560.0$ & $39.9 \pm 0.31$ & $9.9-28.9$ & $23.4 \pm 0.01$ & 90.1 \\
T16 & $0.5-576.0$ & $48.8 \pm 10.2$ & $8.9-28.1$ & $24.6 \pm 0.03$ & 74.3 \\
& & & & & \\
\hline
\end{tabular}




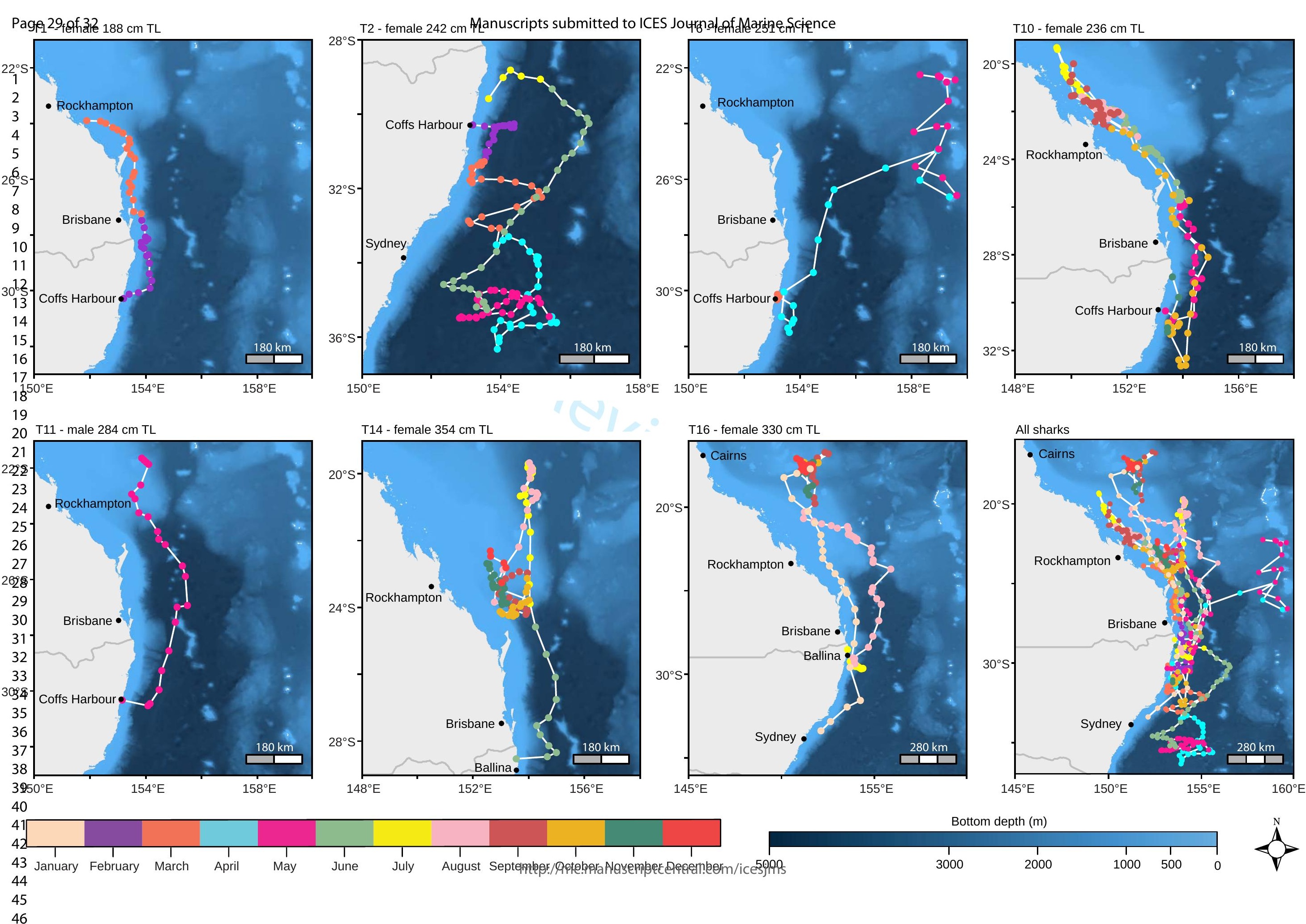


(a)

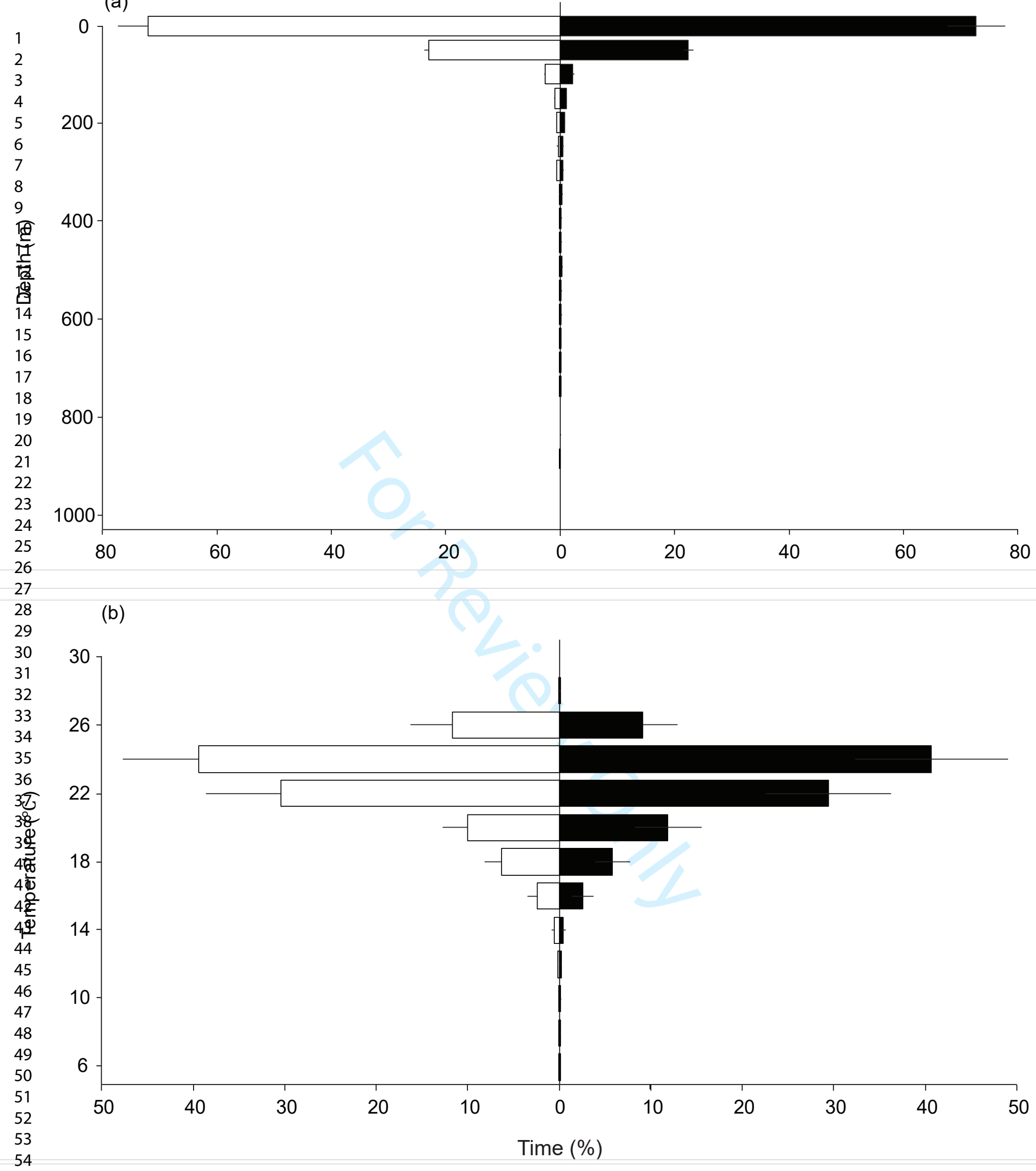


(a) T2

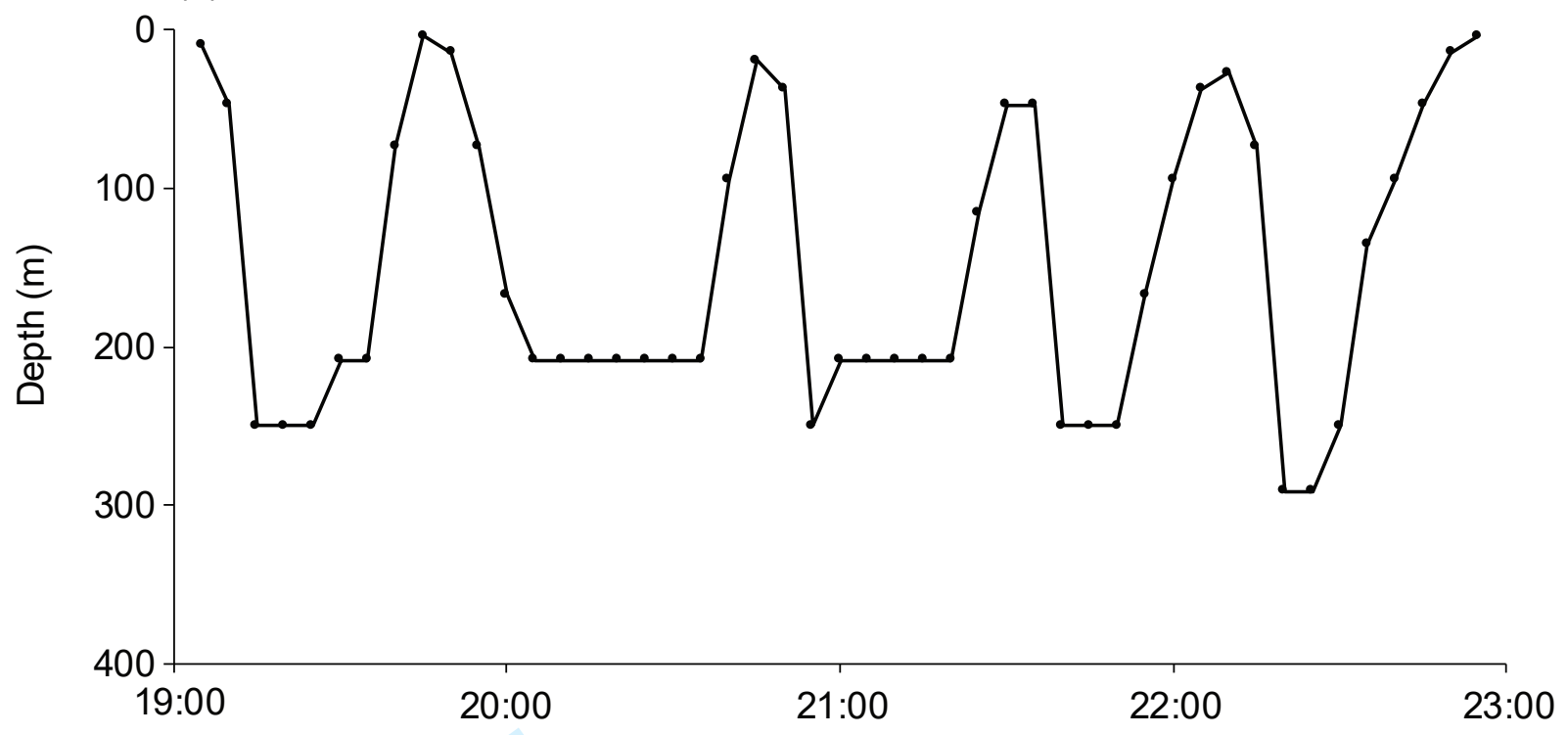

(b) T6

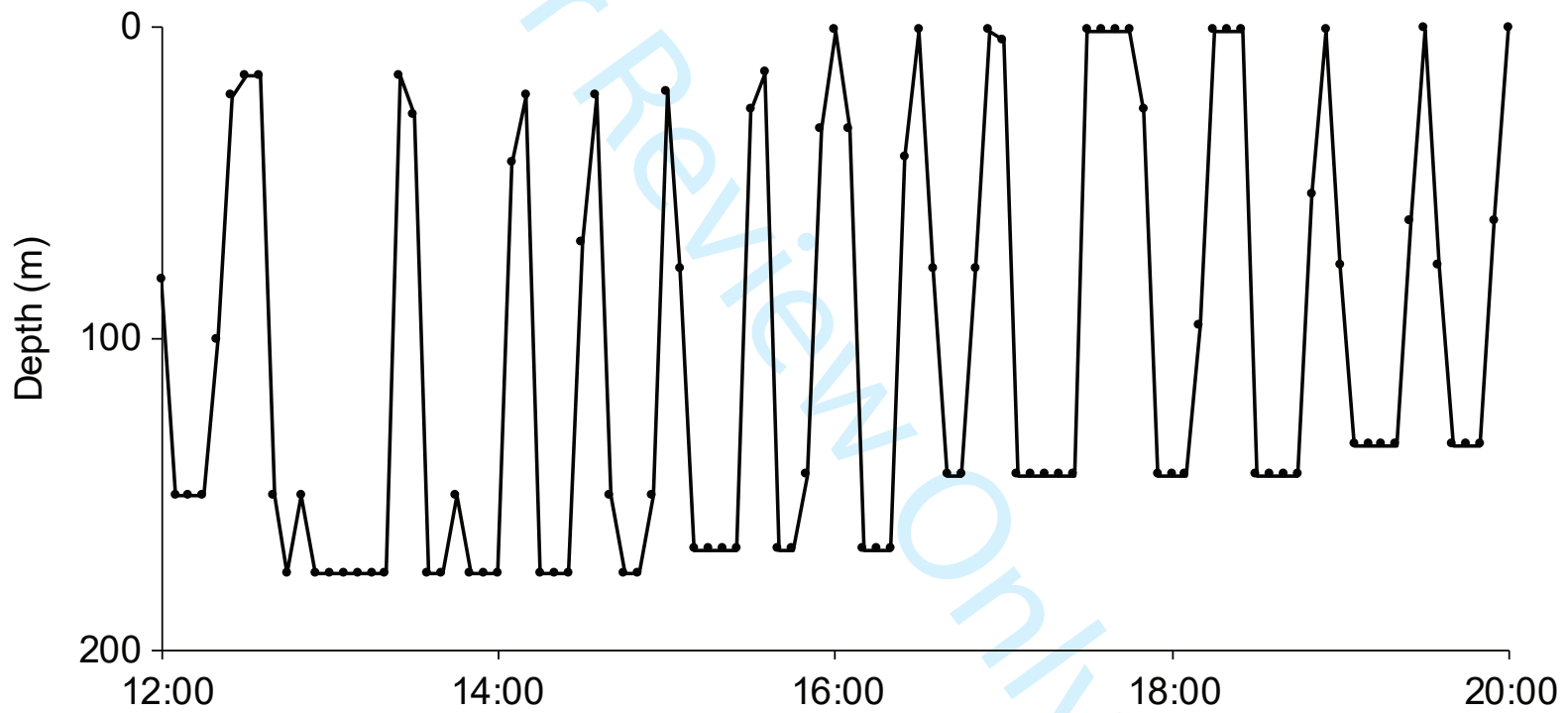

(c) T11

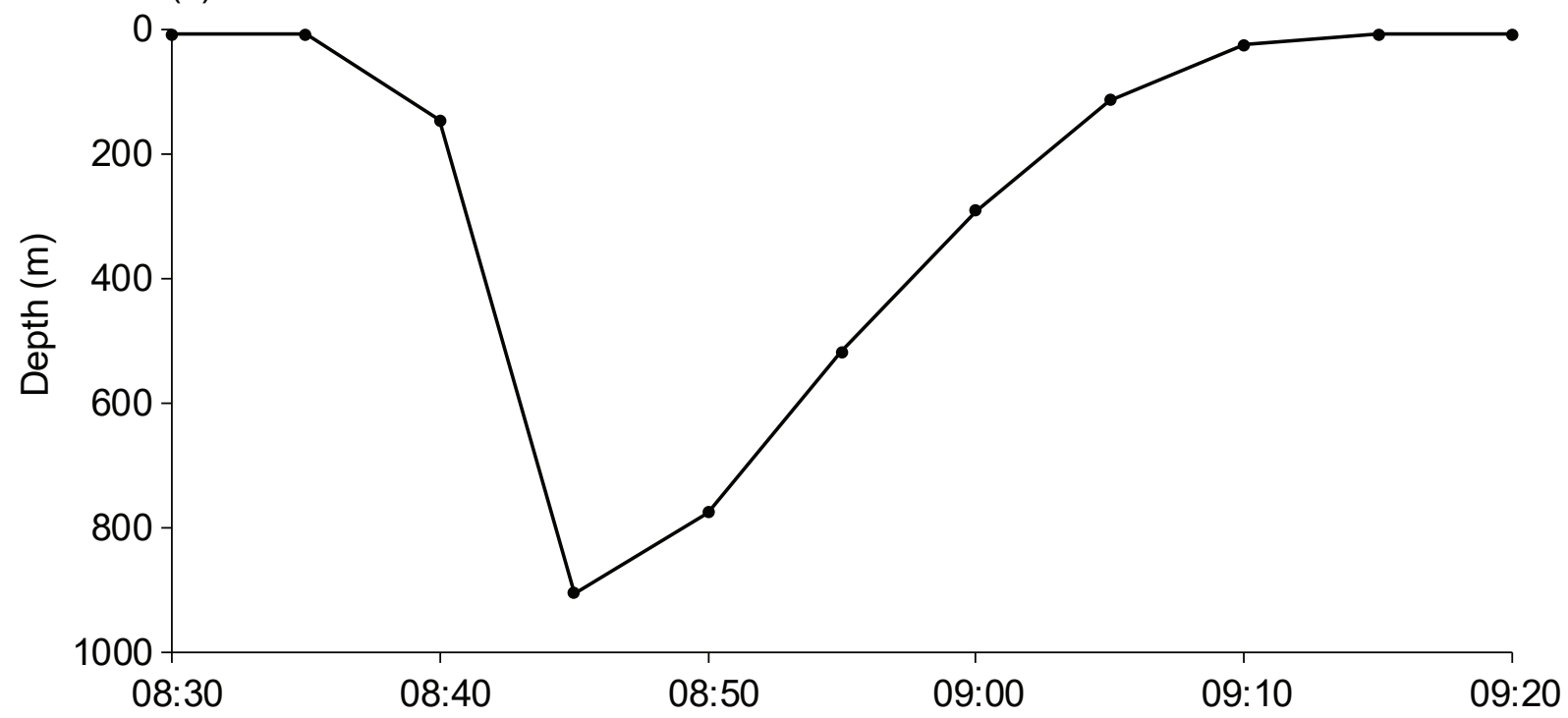

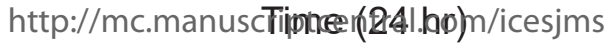

